\title{
Genetic Variability Studies on Twelve Genotypes of Rice (Oryza sativa L.) for Growth and Yield Performance in South Eastern Nigeria
}

\author{
Vincent N. ONYIA, Emeka C. OKECHUKWU, \\ Agatha I. ATUGWU, Ndueso M. AKPAN*
}

\begin{abstract}
University of Nigeria, Nsukka, Faculty of Agriculture, Department of Crop Science, Enugu State, Nigeria; vincent.onyia@unn.edu.ng, emeka.okechukwu@unn.edu.ng,agatha.atugwu@unn.edu.ng,akpandueso@yahoo.com (*orresponding author)
\end{abstract}

\begin{abstract}
Twelve genotypes of rice collected from the National Cereals Research Institute (NCRI), Badeggi, Bida, Niger State, Nigeria were evaluated to estimate the magnitude of genetic variability and relationship of some agronomic traits of rice and their contributions to yield. The results obtained showed a significant difference $(\mathrm{p} \leq 0.05)$ among the genotypes in all the traits studied. Genotype 'WAB 35-1-FX2' produced a significantly higher grain yield of $3.40 \mathrm{t} / \mathrm{ha}$ compared with all the other genotypes in the two years combined. Genotypes 'WAB 33-25', 'WAB 56-1-FX2', 'WAB 56-39', 'WAB 56-125', 'ITA 150' and 'FAROX 16 (LC)' were the most stable grain yielding genotypes across the two years of the experiment. High broad sense heritability $\left(\mathrm{h}_{\mathrm{bs}}{ }^{2}\right)$ was associated with grain yield $\left(\mathrm{h}^{2}{ }_{\mathrm{bs}}=98.63 \%\right)$, number of spikelets/panicle $(98.78 \%)$, plant height $(98.34 \%)$ for the first year planting, whereas in the second year planting, days to $50 \%$ flowering $(96.72 \%)$, days to maturity $(94.14 \%)$ and grain yield (83.33\%) were among the traits that showed high broad sense heritability. The two years combined correlation analysis showed that grain yield correlated significantly and positively with number of spikelets/panicle $\left(r=0.2358^{*}\right)$, number of panicles $/ \mathrm{m}^{2}\left(\mathrm{r}=0.1895^{*}\right)$, number of fertile spikelets/panicle $\left(\mathrm{r}=0.1672^{*}\right)$ and 1,000 grain weight $\left(\mathrm{r}=0.1247^{*}\right)$, indicating that these traits can be phenotypic basis for improving grain yield of rice. Conversely, grain yield exhibited negative correlation with days to $50 \%$ flowering $(-0.3009)$ and days to maturity $(-0.2650)$, though not significant. This suggests that rice grain yield can be improved by selecting early flowering and maturing genotypes especially under heat and drought prone conditions.
\end{abstract}

Keywords: correlation, genetic variance, heritability, rice, variability

\section{Introduction}

Rice (Oryza sativa L.) is the world's second most important cereal crop; it is only exceeded by wheat in terms of demand and production. Rice is the fundamental principal food for about half of the world's population, supplying $20 \%$ of the calories consumed worldwide (Kubo and Purevdorj, 2004). It is a staple food in Africa, especially in Nigeria, Coted'Voire, Gambia, Guinea-Bissau, Liberia, Madagascar, Mauritania, Senegal, Sierra Leone among others (Malton et al., 1998). The world population is expected to reach eight billion by 2030 and rice production must increase by $50 \%$ in order to meet the growing demand (Khush and Brar, 2002). The need for expansion of rice production depends not only on adoption of improved production practices, but also on breeding the available rice cultivars for higher yield productivity.

Plant breeders mostly evaluate their germplasm to generate breeding materials of which the superior lines will be selected for further crop improvement. The success of increasing the productivity of any crop through breeding largely depends on the presence of variability among the breeding materials (Adeyemo and Ojo, 1991; Padulosi, 1993). Genetic variability studies are important in selection of parents for hybridization (Chaudhary and Singh, 1982) because crop improvement depends upon magnitude of genetic variability in base population (Adebisi et al., 2001). Once genetic variability has been ascertained, crop improvement is possible through the use of appropriate selection method, and increasing total yield would be made easier by selecting for yield components because they are more often easily inherited than total yield itself (Ukaoma et al., 2013).

The available variability in a population can be partitioned into genetic and environmental variances, heritability estimates and genetic advance that serve as basis for improving the existing rice genotypes. Therefore, the aim of the research was to evaluate genetic variability among twelve improved rice genotypes collected from the National Cereals Research Institute (NCRI), Badeggi, Bida, Niger State, Nigeria, and to determine agronomic traits that will be used for improving yield of the crop. 


\section{Materials and Methods}

The experiments were carried out in the Department of Crop Science Experimental Farm, Faculty of Agriculture, University of Nigeria, Nsukka, Nigeria, in order to evaluate twelve genotypes of upland rice genotypes collected from the National Cereals Research Institute (NCRI), Badeggi, Bida, Niger State, Nigeria, for high yield performance for two years. The progenies of the first year planting were used for the second year planting. The genotypes used and their sources are listed in Table 1. Nsukka is located on latitude $6^{\circ} 51^{\prime} \mathrm{E}$, and longitude $7^{\circ} 29^{\prime} \mathrm{N}$ of $475 \mathrm{~m}$ above sea level, characterized by lowland humid condition with bimodal annual rainfall distribution that ranges from $1,155 \mathrm{~mm}$ to $1,955 \mathrm{~mm}$, a mean annual temperature of $29{ }^{\circ} \mathrm{C}$ to $31{ }^{\circ} \mathrm{C}$ and relative humidity that ranges from $69 \%$ to $79 \%$ (Uguru et al., 2011).

The experiments were laid out in randomized complete block design (RCBD) with three replications. Plots measuring $4 \times 3 \mathrm{~m}$ each were used for the planting of each genotype. Five seeds were sowed with a spacing of $20 \times 20 \mathrm{~cm}$ per hill and were later thinned down to two seedlings per hill. Inorganic fertilizer of $0.078 \mathrm{~kg}$ urea, $0.2 \mathrm{~kg}$ of single super phosphate and $0.06 \mathrm{~kg}$ of muriate of potash were applied per plot. Urea of $0.078 \mathrm{~kg}$ was also applied to the plots at the booting stage as top dressing. The fertilizers were applied manually between the rows of rice seedlings. Bird scaring was carried out with the aid of a scarecrow and weeding was done manually as when due.

Harvesting was carried out at the hard dough stage when over $90 \%$ of the spikelets were golden and hard, that is at approximately twelve weeks after planting (WAP). Data were collected on the following plant attributes: days to $50 \%$ flowering, plant height $(\mathrm{cm})$, number of tillers/plant, number of panicles $/ \mathrm{m}^{2}$, number of spikelets/panicle, number of fertile spikelets/panicle, days to maturity, 1,000 seed weight (g) and grain yield $(\mathrm{t} / \mathrm{ha})$.

Data obtained were subjected to analysis of variance (ANOVA) following randomized complete block design (RCBD) procedures using GenStat Release 10.3 DE Discovery Edition 4 software (GenStat, 2011). Correlation analysis was done to study relationship among the traits measured.

The phenotypic variation for each trait was partitioned into genetic and non-genetic (environmental) factors according to (Sharma, 1988):

Table 1. List of genotypes used for the study

\begin{tabular}{|c|c|c|}
\hline Trial No. & Material (Entries) & Source \\
\hline 1 & 'WAB32-80' & $\mathrm{NCRI}^{*}$ \\
\hline 2 & 'WAB33-25' & $\mathrm{NCRI}^{*}$ \\
\hline 3 & 'WAB35-1-FX' & $\mathrm{NCRI}^{*}$ \\
\hline 4 & 'WAB56-1-FX' & $\mathrm{NCRI}^{*}$ \\
\hline 5 & 'WAB56-144-FX' & $\mathrm{NCRI}^{*}$ \\
\hline 6 & 'WAB56-39' & $\mathrm{NCRI}^{*}$ \\
\hline 7 & 'WAB56-50' & $\mathrm{NCRI}^{*}$ \\
\hline 8 & 'WAB56-125' & NCRI $^{*}$ \\
\hline 9 & 'WAB99-100' & $\mathrm{NCRI}^{*}$ \\
\hline 10 & 'WAB99-H-14-HB' & $\mathrm{NCRI}^{*}$ \\
\hline 11 & 'ITA 150’ (Standard check) & $\mathrm{NCRI}^{*}$ \\
\hline 12 & 'FAROX 16' (Local check) & NCRI $^{*}$ \\
\hline
\end{tabular}

$\mathrm{Ve}=\mathrm{MS}_{\mathrm{e}} ; \mathrm{V}_{\mathrm{g}}=\left(\mathrm{MS}_{\mathrm{g}}-\mathrm{MS}_{\mathrm{e}}\right) / \mathrm{r} ; \mathrm{V}_{\mathrm{p}}=\mathrm{V}_{\mathrm{g}}+\mathrm{V}_{\mathrm{e}}$

Where $V_{p}, V_{g}$ and $V_{e}$ are phenotypic variance, genotypic variance and environmental variance, respectively, and $\mathrm{MS}_{\mathrm{g}}$, $\mathrm{MS}_{\mathrm{e}}$ and $\mathrm{r}$ are the mean squares of genotypes, mean squares of error and number of replications, respectively. Yield stability studies of the genotypes performance of the two year were done using GenStat Release 10.3 DE Discovery Edition 4 software (GenStat, 2011).

To compare the variations among traits, phenotypic coefficient of variation (PCV), genotypic coefficient of variation $(\mathrm{GCV})$ and environmental coefficient of variation (ECV) were computed according to (Burton, 1952):

$$
\begin{aligned}
& \mathrm{GCV}=\frac{\sqrt{V g}}{X} \times 100 \\
& \mathrm{PCV}=\frac{\sqrt{V p}}{X} \times 100 \\
& \mathrm{ECV}=\frac{\sqrt{V e}}{X} \times 100
\end{aligned}
$$

Where $\mathrm{x}$ is the grand mean for each of the traits measured.

Broad sense heritability $\left(\mathrm{h}^{2} \mathrm{bs}\right)$ expressed as the percentage of the ratio of the genotypic variance $\left(V_{\mathrm{g}}\right)$ to the phenotypic variance $\left(V_{p}\right)$ was estimated as described by (Uguru, 2005; Acquaah, 2007).

$$
\mathrm{H}_{\mathrm{bs}}=\frac{V g}{V p} \times 100
$$

Genetic advance (GA) was estimated by the methods of Johnson et al. (1955) as:

$$
\mathbf{G A}=\mathbf{K} \times \frac{G V}{\sqrt{P V}}
$$

Where $\mathrm{K}$ is a constant (2.06) at $5 \%$ selection intensity, PV is the phenotypic variance and $G V$ is genotypic variance.

\section{Results and Discussion}

The mean squares and genetic parameters of twelve genotypes of rice planted for the two years are presented in Table 2. The analysis of variance showed significant $(\mathrm{p} \leq$ 0.05 ) effects for all the traits studied in both years. The significant differences observed among the genotypes for all the traits in both first and second year plantings suggest the existence of inherent genetic variability among the genotypes (Ndukauba et al., 2015) that can be exploited for improvement.

Agronomic traits performance of the 12 rice genotypes across the two years as presented in Table 2 showed there were significant differences $(\mathrm{p} \leq 0.05)$ in the performance of each genotype across the two years. Genotype 'WAB 35-1FX2' produced highest grain yield of 2.90 and $3.90 \mathrm{t} / \mathrm{ha}$ in the first and second year respectively, followed by 'WAB 56144-FX' genotype (2.80 and $3.50 \mathrm{t} / \mathrm{ha}$ ), while the least was obtained in 'FAROX 16 (LC)' with 1.70 and 2.00 t/ha. 'WAB 56-1-FX2' genotype gave higher weight of 1,000 grain weight of 37.80 and $38.30 \mathrm{~g}$ for first and second year respectively, followed by 'WAB 33-25' genotype (35.70 and $36.70 \mathrm{~g})$, whereas 'WAB 56-39' genotype produced the lowest 1,000 grain weight of 27.80 and $28.18 \mathrm{~g}$ across the years under experiment.

Although there were significant differences in the traits performance of the genotypes across the two years, some maintained a stable performance across both years. This result indicates that the performance of these genotypes is 
Table 2. Agronomic traits performance of the 12 rice genotypes across the two years

\begin{tabular}{|c|c|c|c|c|c|c|c|c|c|c|}
\hline Genotype & Year & $\mathrm{D} 50 \% \mathrm{~F}$ & PH & NT/P & DM & $\mathrm{NP} / \mathrm{M}$ & NS/PA & NFS/PA & $1000-\mathrm{GW}$ & GY \\
\hline \multirow{2}{*}{ 'WAB 32-80' } & 1 & 96.00 & 90.70 & 3.00 & 126.00 & 76.00 & 82.00 & 67.70 & 34.20 & 1.80 \\
\hline & 2 & 80.00 & 91.70 & 3.00 & 110.00 & 126.00 & 98.00 & 77.00 & 33.90 & 2.00 \\
\hline \multirow[t]{2}{*}{ 'WAB 33-25' } & 1 & 97.00 & 100.30 & 3.30 & 127.00 & 78.00 & 97.00 & 65.00 & 35.70 & 2.30 \\
\hline & 2 & 78.00 & 93.00 & 4.70 & 108.00 & 120.00 & 111.00 & 76.70 & 36.70 & 2.60 \\
\hline \multirow[t]{2}{*}{ 'WAB 35-1-FX2' } & 1 & 92.00 & 102.00 & 3.70 & 122.00 & 76.00 & 120.00 & 64.30 & 34.50 & 2.90 \\
\hline & 2 & 81.00 & 92.00 & 5.00 & 111.00 & 120.00 & 111.00 & 73.00 & 35.50 & 3.90 \\
\hline \multirow[t]{2}{*}{ 'WAB 56-1-FX2' } & 1 & 94.00 & 86.70 & 3.70 & 124.00 & 80.00 & 100.00 & 64.30 & 37.80 & 2.60 \\
\hline & 2 & 82.00 & 85.50 & 4.00 & 112.00 & 122.00 & 122.00 & 67.30 & 38.30 & 2.90 \\
\hline \multirow[t]{2}{*}{ 'WAB 56-144-FX' } & 1 & 95.00 & 101.70 & 2.70 & 125.00 & 78.00 & 150.00 & 64.30 & 31.60 & 2.80 \\
\hline & 2 & 79.00 & 101.00 & 5.00 & 109.00 & 120.00 & 126.00 & 76.00 & 32.20 & 3.50 \\
\hline \multirow[t]{2}{*}{ 'WAB 56-39' } & 1 & 103.00 & 83.30 & 3.30 & 133.00 & 55.00 & 122.00 & 69.00 & 27.80 & 2.40 \\
\hline & 2 & 71.00 & 84.50 & 3.30 & 102.00 & 125.00 & 139.00 & 70.00 & 28.10 & 2.70 \\
\hline \multirow[t]{2}{*}{ 'WAB 56-50' } & 1 & 89.00 & 87.70 & 3.70 & 119.00 & 78.00 & 150.00 & 70.70 & 27.90 & 2.20 \\
\hline & 2 & 72.00 & 88.00 & 3.70 & 102.00 & 103.00 & 118.00 & 78.30 & 28.30 & 2.30 \\
\hline \multirow[t]{2}{*}{ 'WAB 56-125' } & 1 & 97.00 & 88.70 & 3.30 & 127.00 & 73.00 & 125.00 & 63.00 & 30.60 & 1.90 \\
\hline & 2 & 75.00 & 88.50 & 3.30 & 105.00 & 117.00 & 128.00 & 77.30 & 29.80 & 2.20 \\
\hline \multirow[t]{2}{*}{ 'WAB 99-100' } & 1 & 98.00 & 87.70 & 3.70 & 128.00 & 75.00 & 108.00 & 59.30 & 30.30 & 2.00 \\
\hline & 2 & 72.00 & 86.00 & 4.30 & 102.00 & 94.00 & 144.00 & 72.30 & 30.80 & 2.20 \\
\hline \multirow[t]{2}{*}{ 'WAB 99-H-14-HB' } & 1 & 94.00 & 88.00 & 3.00 & 124.00 & 54.00 & 90.00 & 68.00 & 30.60 & 2.40 \\
\hline & 2 & 71.00 & 81.50 & 4.00 & 102.00 & 103.00 & 115.00 & 67.30 & 30.50 & 2.60 \\
\hline \multirow[t]{2}{*}{ 'ITA 150’ } & 1 & 88.00 & 93.00 & 3.70 & 118.00 & 53.00 & 87.00 & 63.30 & 32.30 & 1.90 \\
\hline & 2 & 75.00 & 91.00 & 3.30 & 106.00 & 102.00 & 139.00 & 79.70 & 32.60 & 2.20 \\
\hline \multirow[t]{2}{*}{ 'FAROX 16 (LC)' } & & 118.00 & 90.70 & 6.70 & 148.00 & 128.00 & 93.00 & 40.30 & 28.80 & 1.70 \\
\hline & 2 & 80.00 & 97.00 & 6.00 & 110.00 & 133.00 & 132.00 & 77.70 & 28.70 & 2.00 \\
\hline LSD (genotypes) & & 0.75 & 0.52 & 0.29 & 0.52 & 5.25 & 5.06 & 1.58 & 1.02 & 0.05 \\
\hline LSD $(G \times Y)$ & & 5.85 & 1.79 & 0.99 & 1.79 & 18.2 & 17.54 & 5.47 & 3.53 & 0.17 \\
\hline
\end{tabular}

$\overline{\mathrm{D}} 50 \mathrm{~F}=$ Days to $50 \%$ flowering, $\mathrm{PH}=$ Plant height $(\mathrm{cm}), \mathrm{NT} / \mathrm{P}=$ Numbers of tiller per plant, $\mathrm{DM}=$ Days to maturity, $\mathrm{NP} / \mathrm{M}^{2}=\mathrm{Number}$ of panicle per meter square, $\mathrm{NS} / \mathrm{PA}=$ Number of spikelets panicle, NFS/PA= Number of fertile spikelets per plant, $100 \mathrm{WG}=1,000$ seed grain weight $(\mathrm{g})$, GY= Grain yield (tone/ha), G $\times$ Y= Genotypes and year interaction

controlled more by the genetic makeup than the environmental factors. This idea is in accordance with (Lotan et al., 2012) who observed a less fluctuation in rice grain yield over changes in environmental conditions, hence, a variety possessing reasonable stability for yield is desirable for minimizing yield loss over contrasting conditions.

The two years combined agronomic performance of the rice genotypes presented in Table 3 showed significant differences among the genotypes in respect to all the traits except in plant height and number of tiller per plant. Genotype 'WAB 35-1-FX2' exhibited the highest grain yield of $3.40 \mathrm{t} / \mathrm{ha}$ that was significantly different from the other rice genotypes. The lowest grain yield of $1.85 \mathrm{t} / \mathrm{ha}$ was obtained in 'FAROX 16 (LC)', which differed significantly from the other rice genotypes. The result collaborates with (Ukaoma et al., 2013) who observed performance differences among rice genotypes.
The result of grain yield stability performance over the two years presented in Table 4 revealed that genotypes 'WAB 3325', 'WAB 56-1-FX2', 'WAB 56-39', 'WAB 56-125', 'ITA 150 ' and 'FAROX 16 (LC)' were the most stable genotypes, as they exhibited the lowest interaction principal component axis 1 (IPCA 1 ) value of 0.046 , while the least stable genotype was obtained in 'WAB 35-1-FX2'. Stable genotypes are less dependent upon good environments to perform well, and this makes their yield more predictable (Biswas et al., 2011). However, Al-Otayk (2010) argued that a genotype with stable and high yield across different environments would be a more suitable cultivar and perhaps a donor parent for further breeding programme. Thus, genotypes 'WAB 56-1-FX2', 'WAB 56-39', 'WAB 99-H-14-HB' and 'WAB 33-25' are recommended for use owing to their high grain yield and stability.

Table 3. Agronomic traits performance of the 12 rice genotypes for the two years combined

\begin{tabular}{ccccccccccc}
\hline Genotype & D5\%F & PH & NT/P & DM & NP/M & NS/PA & NFS/PA & $1000-G W$ & GY \\
\hline 'WAB 32-80' & 88.00 & 91.50 & 3.00 & 110.00 & 101.00 & 82.00 & 67.70 & 34.20 & 1.90 \\
'WAB 33-25' & 88.00 & 96.50 & 4.00 & 111.00 & 99.00 & 97.00 & 64.30 \\
'WAB 35-1-FX2' & 87.00 & 97.00 & 4.50 & 111.00 & 98.00 & 120.00 & 64.30 & 34.50 & 3.40 \\
'WAB 56-1-FX2' & 88.00 & 85.50 & 4.00 & 110.00 & 101.00 & 100.00 & 64.30 & 37.80 & 2.75 \\
'WAB 56-144-FX' & 87.00 & 101.00 & 3.85 & 108.00 & 99.00 & 150.00 & 64.30 & 31.60 & 3.15 \\
'WAB 56-39' & 87.00 & 84.50 & 3.30 & 107.00 & 90.00 & 122.00 & 69.00 & 27.80 & 2.55 \\
'WAB 56-50' & 80.00 & 88.00 & 3.70 & 107.00 & 91.00 & 150.00 & 70.70 & 27.90 & 2.25 \\
'WAB 56-125' & 86.00 & 88.50 & 3.30 & 110.00 & 95.00 & 108.00 & 63.00 & 30.60 & 2.05 \\
'WAB 99-100' & 85.00 & 86.00 & 4.00 & 112.00 & 85.00 & 108.00 & 59.30 & 30.30 & 2.10 \\
'WAB 99-H-14-HB' & 82.00 & 81.50 & 3.50 & 112.00 & 78.00 & 90.00 & 68.00 & 30.60 & 2.50 \\
'ITA 150' & 82.00 & 91.00 & 3.50 & 110.00 & 71.00 & 87.00 & 63.30 & 32.30 & 2.05 \\
'FAROX 16 (LC)' & 99.00 & 97.00 & 6.35 & 127.00 & 131.00 & 93.00 & 40.30 & 28.80 & 1.85 \\
LSD (years) & 1.85 & ns & ns & 1.26 & 12.87 & 13.88 & 3.87 & 2.49 & 0.12
\end{tabular}

$\mathrm{D} 50 \mathrm{~F}=$ Days to $50 \%$ flowering, $\mathrm{PH}=$ Plant height $(\mathrm{cm}), \mathrm{NT} / \mathrm{P}=$ Numbers of tiller per plant, $\mathrm{DM}=$ Days to maturity, NP/M$=\mathrm{Mumber}$ of panicle per meter square,

NS/PA= Number of spikelets panicle, NFS/PA= Number of fertile spikelets per plant, $100 \mathrm{WG}=1,000$ seed grain weight $(\mathrm{g})$, GY= Grain yield (tone/ha) 
Table 4. Grain yield performance and stability of the 12 rice genotypes for the two years

\begin{tabular}{|c|c|c|c|c|}
\hline Genotype & Mean grain yield $(\mathrm{t} / \mathrm{ha})$ & IPCA 1 & IPCA 2 & Stability rank \\
\hline 'WAB 32-80' & 1.900 & 0.138 & 0.000 & 2 \\
\hline 'WAB 33-25' & 2.450 & 0.046 & 0.000 & 1 \\
\hline 'WAB 35-1-FX2' & 3.400 & -0.599 & 0.000 & 5 \\
\hline 'WAB 56-1-FX2' & 2.750 & 0.046 & 0.000 & 1 \\
\hline 'WAB 56-144-FX' & 3.150 & -0.322 & 0.000 & 4 \\
\hline 'WAB 56-39' & 2.550 & 0.046 & 0.000 & 1 \\
\hline 'WAB 56-50’ & 2.250 & 0.230 & 0.000 & 3 \\
\hline 'WAB 56-125' & 2.050 & 0.046 & 0.000 & 1 \\
\hline 'WAB 99-100’ & 2.100 & 0.138 & 0.000 & 2 \\
\hline ‘WAB 99-H-14-HB' & 2.500 & 0.138 & 0.000 & 2 \\
\hline 'ITA 150’ & 2.050 & 0.046 & 0.000 & 1 \\
\hline 'FAROX 16 (LC)' & 1.850 & 0.046 & 0.000 & 1 \\
\hline
\end{tabular}

Genetic variation in populations of crop species is important for successful selection and yield improvement programs (Idahosa et al., 2010). Genotypic variances ranging from 0.72 (grain yield) to 542.98 (number of spikelets/panicle) and phenotypic variances ranging from 0.73 (grain yield) to 549.69 (number of spikelets/panicle) among the agronomic traits considered were obtained in the first year planting. In the second year planting, genotypic variances ranged from 0.10 (grain yield) to 114.37 (number of spikelets/panicle), whereas phenotypic variances ranged from 0.12 (grain yield) to 370.42 (number of spikelets/panicle). High genotypic variance values of $542.98,382.01$, and 75.27 were obtained for number of spikelets/panicle, number of panicles $/ \mathrm{m}^{2}$ and days to maturity, respectively in first year planting. Similarly, high genotypic variances of $114.37,79.69$ and 15.90 were also obtained for number of spikelets/panicle, number of panicles $/ \mathrm{m}^{2}$ and days to $50 \%$ flowering, respectively in second year planting (Table 5).

Genotypic coefficient of variation (GCV) provides a measure of genetic variability present in various quantitative traits. High amount of GCV was obtained in grain yield
(38.57\%) followed by number of tillers/plant (26.21\%) and number of panicle $/ \mathrm{m}^{2}$ (25.97\%) and a phenotypic coefficient of variation (PCV) of $38.84 \%, 31.91 \%$ and $25.97 \%$, respectively, while the least GCV and PCV was obtained in days to maturity of $6.83 \%$ and $6.90 \%$, respectively in the first year planting. The results obtained for the second year planting showed that number of tillers/plant (20.62\%) had the highest GCV, followed by grain yield (12.16\%) and number of spikelets/panicle (8.62\%). PCV of $24.24 \%$ for number of tillers/plant, seconded by number of spikelets/panicle $(15.52 \%)$ and 1,000 grain weight $(14.53 \%)$ were observed. The lowest GCV and PCV were obtained in days to maturity of $3.02 \%$ and $3.12 \%$, respectively (Table 5). Coefficients of variation studies indicated that the estimates of $\mathrm{PCV}$ were slightly higher than the corresponding GCV estimates for all the traits studied, indicating that the characters were less influenced by the environment. Devi et al. (2006), Prajapati $e t$ al. (2011) and Sandhya et al. (2014) earlier also reported similar result as observed in this present study in rice. Therefore, selection on the basis of phenotype alone can be effective for the improvement of these traits.

Table 5. Variance, broad sense heritability and genetic advance estimates for nine agronomic characters for the twelve (12) rice genotypes across the two years of the experiment

\begin{tabular}{|c|c|c|c|c|c|c|c|c|c|c|}
\hline $\begin{array}{l}\text { Treat } \\
\text { Year } 1\end{array}$ & Mean & Msg & $\mathrm{Ve}$ & $\mathrm{Vg}$ & $\mathrm{Vp}$ & GCV & PCV & ECV & $\mathrm{Hb}$ & GA \\
\hline $50 \% \mathrm{~F}$ & 96.80 & $182.80^{* *}$ & 3.77 & 59.68 & 63.45 & 7.98 & 8.23 & 2.01 & 94.06 & 15.43 \\
\hline $\mathrm{PH}$ & 90.70 & $220.98^{*}$ & 1.24 & 73.25 & 74.49 & 9.44 & 9.52 & 1.23 & 98.34 & 17.48 \\
\hline NT/P & 3.60 & $3.06^{* *}$ & 0.45 & 0.87 & 1.32 & 26.21 & 31.91 & 18.63 & 65.91 & 1.56 \\
\hline DM & 127.00 & $227.4^{*}$ & 1.60 & 75.27 & 76.87 & 6.83 & 6.90 & 1.00 & 97.92 & 17.68 \\
\hline $\mathrm{NP} / \mathrm{M}^{2}$ & 75.25 & $1158.08^{*}$ & 12.06 & 382.01 & 394.07 & 25.97 & 26.38 & 4.61 & 96.94 & 39.64 \\
\hline NS/PA & 110.70 & $1635.66^{*}$ & 6.71 & 542.98 & 549.69 & 21.05 & 21.18 & 2.34 & 98.78 & 47.70 \\
\hline NFS/PA & 63.30 & $187.06^{*}$ & 16.39 & 56.89 & 73.28 & 11.92 & 13.52 & 3.99 & 77.63 & 13.69 \\
\hline $1000 \mathrm{GW}$ & 31.90 & $32.88^{*}$ & 3.84 & 9.68 & 13.52 & 9.75 & 11.53 & 6.14 & 71.6 & 5.42 \\
\hline GY & 2.20 & $0.05^{*}$ & 0.01 & 0.72 & 0.73 & 38.57 & 38.84 & 4.55 & 98.63 & 1.74 \\
\hline \multicolumn{11}{|l|}{ Year2 } \\
\hline $50 \% \mathrm{~F}$ & 76.60 & $48.23^{* *}$ & 0.54 & 15.90 & 16.44 & 5.21 & 5.29 & 0.96 & 96.72 & 8.09 \\
\hline $\mathrm{PH}$ & 90.30 & $63.33^{* *}$ & 21.39 & 13.98 & 35.37 & 4.14 & 6.59 & 5.12 & 39.53 & 4.84 \\
\hline NT/P & 4.00 & $2.31^{*}$ & 0.26 & 0.68 & 0.94 & 20.62 & 24.24 & 12.75 & 72.34 & 1.44 \\
\hline DM & 106.00 & $31.49^{*}$ & 0.64 & 10.28 & 10.92 & 3.02 & 3.12 & 0.75 & 94.14 & 6.42 \\
\hline $\mathrm{NP} / \mathrm{M}^{2}$ & 115.42 & $314.69^{*}$ & 75.63 & 79.69 & 155.32 & 7.73 & 10.80 & 7.53 & 51.31 & 13.18 \\
\hline NS/PA & 124.00 & $569.15^{*}$ & 226.05 & 114.37 & 370.42 & 8.62 & 15.52 & 12.12 & 30.88 & 12.24 \\
\hline NFS/PA & 74.30 & $55.20^{*}$ & 9.76 & 15.15 & 24.91 & 5.24 & 6.72 & 4.20 & 60.82 & 6.25 \\
\hline $1000 \mathrm{GW}$ & 32.12 & $34.31^{*}$ & 15.52 & 6.26 & 21.78 & 7.79 & 14.53 & 12.27 & 28.74 & 2.76 \\
\hline GY & 2.60 & $0.12^{*}$ & 0.02 & 0.10 & 0.12 & 12.16 & 13.32 & 5.44 & 83.33 & 0.59 \\
\hline
\end{tabular}

${ }^{* * *}$ Significant at $5 \%$ and $1 \%$ level, D50F = Davs to $50 \%$ flowering, $\mathrm{PH}=$ Plant height $(\mathrm{cm}), \mathrm{NT} / \mathrm{P}=$ Numbers of tiller per plant, DM = Days to maturity, $\mathrm{NP} / \mathrm{M} 2=$ Number of panicle per meter square, NS/PA = Number of spikelets panicle, NFS/PA= Number of fertile spikelets per plant, $100 \mathrm{WG}=1,000$ seed grain weight $(\mathrm{g}), \mathrm{GY}=$ Grain yield (tone/ha), Msg= mean square of the genotypes, Ve= Environmental variance, Vg= Genotypic variance, Vp= Phenotypic variance, \%C.V= Percentage coefficient of variation, GCV= Genotypic coefficient of variation, PCV = Phenotypic coefficient of variation, ECV=Environmental coefficient of variation, $\mathrm{Hbs}=$ Broad sense heritability (\%), GA= Genetic advance 
Table 6. Correlation coefficients of yield and other key agronomic traits of the 12 rice genotypes for the two years combined

\begin{tabular}{|c|c|c|c|c|c|c|c|c|c|}
\hline & D50\%F & $\mathrm{PH}$ & NT/P & $\mathrm{NP} / \mathrm{M}^{2}$ & NS/PA & NFS/PA & DM & $100-\mathrm{GW}$ & GY \\
\hline D50\%F & 1 & 0.1743 & 0.0829 & $-0.665^{* * *}$ & $-0.3802^{* *}$ & $-0.760^{* * *}$ & $-0.1053^{* *}$ & $0.01015^{\text {ns }}$ & $-0.3009^{n}$ \\
\hline $\mathrm{PH}$ & & 1 & $0.2803^{*}$ & $0.2627^{*}$ & 0.0826 & $-0.132^{*}$ & 0.0664 & $0.2412^{*}$ & $0.1635^{\mathrm{ns}}$ \\
\hline NT/P & & & 1 & $0.5056^{* * *}$ & -0.0365 & $-0.2321^{*}$ & 0.0049 & $-0.0772^{\text {ns }}$ & $0.0419^{\mathrm{ns}}$ \\
\hline $\mathrm{NP} / \mathrm{M}^{2}$ & & & & 1 & 0.1906 & $0.250^{*}$ & 0.0119 & $0.0044^{\mathrm{ns}}$ & $0.1895^{*}$ \\
\hline NS/PA & & & & & 1 & $-0.1526^{\mathrm{ns}}$ & $0.4380^{* * *}$ & $0.1596^{\mathrm{ns}}$ & $0.2358^{*}$ \\
\hline NFS/PA & & & & & & 1 & $0.1052^{\mathrm{ns}}$ & $-0.2747^{*}$ & $0.1672 *$ \\
\hline DM & & & & & & & 1 & 0.009 ns & $-0.2650^{\mathrm{n}}$ \\
\hline 1000GW & & & & & & & & 1 & $0.1247^{*}$ \\
\hline GY & & & & & & & & & 1 \\
\hline
\end{tabular}

*** Significant at $5 \%$ and $1 \%$ level, respectively, ns=Not significant, D $50 \mathrm{~F}=$ Days to $50 \%$ flowering, $\mathrm{PH}=$ Plant height $(\mathrm{cm}), \mathrm{NT} / \mathrm{P}=\mathrm{Numbers}$ of tiller per plant, DM= Days to maturity, NP/M2=Number of panicle per meter square, NS/PA= Number of spikelets panicle, NFS/PA= Number of fertile spikelets per plant, $100 \mathrm{WG}=1,000$ seed grain weight $(\mathrm{g}), \mathrm{GY}=$ Grain yield (tone $/$ ha)

In the first year planting, high broad sense heritability $\left(\mathrm{h}_{\mathrm{bs}}^{2}\right)$ estimates were recorded for number of spikelets/panicle (98.78\%), grain yield (98.63\%), plant height $(98.34 \%)$ and days to maturity (97.92\%), while the results for second year planting experiment showed that days to $50 \%$ flowering (96.72\%), days to maturity (94.14\%), grain yield $(83.33 \%)$ and number of tillers/panicle $(72.34 \%)$ were among traits with high broad sense heritability (Table 5). The results suggested that these traits would respond to selection owing to their high genetic variability and heritability. Similar findings were also reported by Anandrao et al., 2011, Sandhya et al., 2014. A perusal of genetic advance for all the quantitative characters under study ranged from 1.56 (number of tillers/plant) to 47.70 (number of spikelets per panicle). High genetic advance was observed for number of spikelets/panicle (47.70) and number of panicle $/ \mathrm{m}^{2}$ (39.64). Days to maturity (17.68), plant height (17.48), days to $50 \%$ flowering (15.43) and number of fertile spikelets/panicle (13.69) showed moderate genetic advance. Lowest genetic advance was observed for number of tillers/plant (1.56) followed by grain yield (1.74) and 1,000 grain weight (5.42) for the first year planting. For the second year, the number of panicle $/ \mathrm{m}^{2}$ showed a moderate genetic advance of 13.18 , followed by number of fertile spikelets/panicle (12.24). Grain yield, number of tillers/plant and 1,000 grain weight showed a low genetic advance of $0.59,1.44$ and 2.76 , respectively. High heritability coupled with high genetic advance was observed for number of spikelets/panicle and number of panicle $/ \mathrm{m}^{2}$. This indicates the lesser influence of environment in expression of these characters and prevalence of additive gene action in their inheritance hence, amenable for simple selection. Days to $50 \%$ flowering, plant height, days to maturity and number of fertile spikelets/panicle had high heritability with moderate genetic advance, indicating that the characters were also governed by both additive and nonadditive gene actions. Similar results were reported by Vivek et al. (2005), Jayasudha and Sharma (2010) and Sandhya et al. (2014).

Correlation of yield and other traits is important in indirect selection for high yield improvement in crop genotypes (Machikowa and Laosuwan, 2011). The results of the correlation coefficient among some agronomic traits of rice are shown in Table 6 . The mean of both years were used for the correlation analysis. There was a significant and positive correlation of grain yield with number of panicle $/ \mathrm{m}^{2}$ $(\mathrm{r}=0.1895, \mathrm{p} \leq 0.05)$, number of spikelets/panicle $(\mathrm{r}=$ $0.2358, \mathrm{p} \leq 0.05)$, number of fertile spikelets/panicle $(\mathrm{r}=$ $0.1672, \mathrm{p} \leq 0.05)$ and 1,000 grain weight $(\mathrm{r}=0.1247, \mathrm{p} \leq$
0.05). Grain yield had positive, but non-significant correlation with plant height $(\mathrm{r}=0.1635)$ and number of tillers/plant $(r=0.0419)$. Conversely, grain yield exhibited negative correlation with days to $50 \%$ flowering $(-0.3009)$, and days to maturity $(-0.2650)$, but not significant. The significant and positive correlation between grain yield and number of panicle $/ \mathrm{m}^{2}$, number of spikelets/panicle, number of fertile spikelets/panicle and 1,000 grain weight is a strong indication that these traits are major factors in improving grain yield of rice. This suggests that selection directed towards these characters will be effective in ensuring high grain yield in rice. These results collaborate with the finding of Ogunbayo et al. (2014) who observed a positive and significant correlation between grain yield and number of panicle $/ \mathrm{m}^{2}$. The negative correlation obtained between days to $50 \%$ flowering, days to maturity and grain yield indicate that grain yield can be improved by selecting early flowering and maturing genotypes.

\section{Conclusions}

In conclusion, the two years combined agronomic performance of the rice genotypes showed significant differences among the genotypes in respect to all the traits. Genotype 'WAB 35-1-FX2' exhibited the highest grain yield significantly different from the other rice genotypes. Mean of both years used for the correlation analysis showed a significant and positive correlation of grain yield with number of panicle $/ \mathrm{m}^{2}$, number of spikelets/panicle, number of fertile spikelets/panicle and 1,000 grain weight.

\section{References}

Acquaah G (2007). Principles of plant genetics and breeding. Blackwell Publishing, Oxford.

Adebisi MA, Ariyo OJ, Kehinde OB (2001). Variation and correlation studies in quantitative characteristics in soybean. Proceedings of the $35^{\text {th }}$ Annual conference of the Agricultural Society of Nigeria held at the University of Agriculture, Abeokuta September 2001 1620:121-125.

Adeyemo MO, Ojo AA (1991). Genetic variability and associations of some agronomic traits and seed yield in sesame (Sesamum indicum L.). Nigerian Journal of Genetics 8:39-44.

Al-Otayk SM (2010). Performance of yield and stability of wheat genotypes under high stress environments of the central region of 
Saudi Arabia. Meteorology, Environment and Arid Land Agriculture Sciences 21(1):81-92.

Anandrao SD, Singh CM, Suresh BG, Lavanya GR (2011). Evaluation of rice hybrids for yield and yield component characters under North East Plain Zone. The Allahabad Farmer 67(1):63-68.

Biswas PL, Barman HN, Ghosal S, Tohiduzzaan S, Ali MH (2011). Stability study for growth duration and grain yield of exotic hybrid rice genotypes in Bangladesh. Bangladesh Journal of Agricultural Research 36(91):97-102.

Burton GW (1952). Qualitative inheritance in grasses. Proceedings of the $6^{\text {th }}$ International Grassland Congress, Pennsylvania Pa., USA 1:277-283.

Chaudhary VS, Singh BB (1982). Heterosis and genetic variability in relation to genetic diversity in soybean. Indian Journal of Genetics 42:324-328.

Devi SL, Raina FA, Pandey MK, Cole CR (2006). Genetic parameters of variation for grain yield and its components in rice. Crop Research 32(1):69-71.

GenStat (2011). GenStat Release 10.3DE (PC/Windows 7) 23 August 2012 09:45:52 Copyright 2011, VSN International Ltd. (Rothamsted Experimental Station).

Idahosa DO, Alika JE, Omoregie AU (2010). Genetic variability, heritability and expressed genetic advance as indices for yield and yield components selection in cowpea (Vigna unguiculata (L) Walp. Academia Arena 2(5):22-26.

Jack TJ (1972). Cucurbit seed: I Characterization and uses of oil and proteins. A Review. Economic Botany 26(2):135-141.

Jayasudha S, Sharma D (2010). Genetic parameters of variability, correlation and path-coefficient for grain yield and physiological traits in Rice (Oryza sativa L.) under shallow lowland situation. Electronic Journal of Plant Breed 1(5):33-38.

Johnson HN, Robinson HF, Constock RE (1955). Genotypic and phenotypic correlation in soybean and their implication in selection. Agronomy Journal 47(10):477-483.

Khush GS, Brar DS (2002). Biotechnology for rice breeding: progress and impact. In: Sustainable rice production for food security. Proceedings of the $20^{\text {th }}$ Session of the International Rice Commission. Bangkok, Thailand, July 23-26.

Kubo M, Purevdorj M (2004). The future of rice production and consumption. Journal of Food Distribution Research 35(1):128142.

Lotan KR, Marella N, Onkar NS (2012). Genoype $\times$ Environment interaction and stability analysis of lowland rice genotypes. Journal of Agricultural Sciences 57(1):1-8.
Machikowa T, Laosuwan P (2011). Path coefficient analysis for yield of early maturing soybean. Sonklanakarin Journal of Science and Technology 33(4):365-368.

Malton P, Randolph T, Guei R (1998). Impact of rice research in West Africa. In: Prabhu L, Pangali MH (Eds). Impact of rice research Thailand Development Research, International Rice Research Institute (IRRI), Manila Philippines pp 383-404.

Ndukauba J, Nwofia GE, Okocha PI, Ene-Obong EE (2015). Variability in Egusi-Melon genotypes (Citrullus lanatus (Thumb) Matsum and Nakai) in derived savannah environment in SouthEastern Nigeria. International Journal of Plant Research 5(1):19-26

Ogunbayo SA, Sie M, Ojo DK, Sanni KA, Akinwale MG, Toulou B, Shuttu A, Idehen EO, Popoola AR, Daniel IO, Gregorio GB (2014). Genetic variation and heritability of yield and related traits in promising rice genotypes (Oryza sativa L). Journal of Plant Breeding and Crop Science 6(11):153-159.

Padulosi S (1993). Genetic diversity, taxonomy and ecogeographical survey of the wild relatives of cowpea (Vigna uniguiculata L. Walp). $\mathrm{PhD}$ Thesis, University of Louvain-La-Neuve, Belgium.

Prajapati M, Singh CM, Suresh G, Lavanya GR, Jadhav P (2011). Genetic parameters for grain yield and its component characters in rice. Electronic Journal of Plant Breeding 2(2):235-238.

Sandhya GR, Lavanya G, Suresh B, Ravi K, Satish KR, Bandana D (2014). Study of genetic variability and $\mathrm{D}^{2}$ analysis in elite rice genotypes International Journal of Food, Agriculture and Veterinary Sciences 4(2):12-16.

Sharma JR (1988). Statistical and biometrical techniques in plant breeding. New Age International Limited Publishers, New Delhi.

Uguru MI (2005). Crop genetics and breeding. 2nd edition, Ephrata Press, Nsukka.

Uguru MI, Baiyeri KP, Abba SC (2011). Indicators of climate change in the derived savannah niche on Nsukka, South-Eastern Nigeria. Agro-Science 10(1):1-10.

Ukaoma AA, Okocha PI, Okechukwu RI (2013). Heritability and character correlation among some rice genotypes. Journal of Plant Breeding and Genetics 1(2):73-84.

Vivek S, Singh S, Singh SK, Singh H (2005). Estimation of genetic variability, heritability and genetic advance in rice (Oryza sativa L.). Agriculture Science Digest 25(3):207-209. 